\title{
KONTRIBUSI ANGGOTA LEGISLATIF PEREMPUAN TERHADAP KEPENTINGAN PEREMPUAN
}

\author{
(Studi Kasus: Anggota Legislatif Perempuan DPRD Kabupaten Bungo \\ Periode 2014-2019)
}

\author{
Andila Yunika 1), Indah Adi Putri 2), Asrinaldi ${ }^{3)}$ \\ 1,2,3) Megister Ilmu Politik, Universitas Andalas, Padang, Indonesia
}

\begin{abstract}
Abstrak
Posisi perempuan di DPRD penting untuk mengangkat isu-isu masalah perempuan. Keterwakilan perempuan diharapkan bisa menghasilkan produk-produk kebijakan yang pro terhadap kepentingan perempuan.Penelitian ini berfokus pada penyebab anggota legislatif perempuan di DPRD kabupaten Bungo tidak bisa berkontribusi terhadap kepentingan perempuan Kabupaten Bungo. Teori yang digunakan dalam penelitian ini yaitu keteterwakilan politik perempuan : Politics of Idea dan Politics of Presence dari Anne Phillips. Hasil penelitian ini menemukan bahwa kehadiran anggota legislatif perempuan di DPRD hanya sebatas kehadiran deskriptif, tidak termasuk kepada kehadiran subtantif apalgi kehadiran transformatif (Politics of Presence). Sehingga mereka tidak bisa memberikan gagasan dan ide-ide (Politics of Idea) yang terkait dengan masalah serta isu-isu perempuan di Kabupaten Bungo. Penyebabnya pertama, anggota legislatif perempuan tidak memahami keterwakilan perempuan dan kedua, motivasi awal anggota legislatif perempuan ikut pemilihan legislatif karena uang (money politics) dan peluang.
\end{abstract}

Kata kunci: Keterwakilan Perempuan, dan Legislatif

*Correspondence Address : andilayunika@gmail.com DOI : $10.31604 /$ jips.v6i2.2019.417-427

(C)2019 Fakultas Keguruan \& Ilmu Pendidikan UM-Tapanuli Selatan 


\section{PENDAHULUAN}

Perempuan akan selalu menjadi topik menarik dalam perbincangan dunia politik. Potret buram kehidupannya yang kerap diterpa perlakuan diskriminatif menjadi alasan betapa nasib dan masa depan perempuan perlu diperjuangkan. Faktanya, hingga saat ini berbagai persoalan seperti kemiskinan, kekerasan, pelecehan, dan bentuk ketidakadilan lainnya masih menjadi persoalan krusial yang memunculkan prejudice bahwa perempuan merupakan warga negara kelas kedua (second class citizenship). Sejumlah kalangan berkeyakinan, persoalan tersebut bisa dihilangkan jika perempuan terlibat langsung dalam gelanggang pemutus kebijakan politik di parlemen.

Keterlibatan perempuan dan lakilaki di bidang politik adalah bagian tidak terpisahkan dalam proses demokratisasi. Perempuan mulai diikutsertakan dalam partai-partai politik, sebagai upaya rekonstitusi formasi politik yang ada sebelumnya. Partai politik berpeluang untuk menentukan partisipasi dan keterwakilan perempuan. Usaha ini juga telah mendapat dukungan dengan adanya Undang-Undang dan peraturan yang melarang segala bentuk deskriminasi ras,agama, dan gender. Misalnya, Undang-Undang No.8 Tahun 2012 tentang keterlibatan perempuan dalam partai politik. Selain itu, Pasal 53 UU Pemilu Legislatif tersebut juga menyatakan daftar bakal calon juga memuat paling sedikit $30 \%$ keterwakilan perempuan.

Mayoritas laki-laki di DPRD sulit diharapkan untuk memperjuangkan kepentingan perempuan sebab mereka tidak mengalami dan memahami apa yang dirasakan dan diinginkan perempuan. Oleh sebab itu, maka posisi perempuan dalam DPRD penting untuk mengangkat isu-isu masalah perempuan. Perempuan memiliki kebutuhan khusus yang hanya dapat dipahami dengan baik oleh perempuan itu sendiri, antara lain : Isu-isu kesehatan reproduksi, Isu-isu kesejahteraan keluarga, Isu-isu kekerasan dan pelecehan seksual.

Pada periode 2014-2019, jumlah anggota legislatif DPRD Kabupaten Bungo sebanyak 35 orang dengan komposisi menurut jenis kelamin yaitu 29 orang anggota legislatif laki-laki dan 6 orang anggota legislatif perempuan.

Enam anggota legislatif perempuan yang duduk di DPRD Bungo memiliki peluang besar untuk mengusulkan 
sebuah peraturan daerah yang melindungi perempuan guna untuk memenuhi kepentingan perempuan di Kabupaten Bungo. Tetapi, faktanya peraturan daerah yang dihasilkan dalam periode 2014-2019 sebanyak 72 Peraturan Daerah, tetapi tidak ada satu pun perda yang ada terkait kepentingan perempuan. Peraturan Daerah meliputi Perda dari Pemerintah Daerah dan Perda Inisiatif yang datang dari anggota legislatif itu sendiri.

Berdsarkan pada data di atas maka peneliti berasumsi bahwa para anggota legislatif perempuan yang duduk di DPRD Kabupaten Bungo dari periode 2014-2019 tidak mampu memberikan kontribusi apapun terkait kepentingan perempuan di Kabupaten Bungo.

Terkait dengan konsep keterwakilan, Anne Phillips mengatakan bahwa politik untuk kalangan perempuan bukan hanya dimaknai sebagai pertarungan ide dan gagasan tetapi juga diartikan dalam kehadiran yang memberi makna sebagai agen dalam lembaga perwakilan rakyat untuk mewakili kepentingan dan kebutuhan perempuan tidak dapat diabaikan.
Keterwakilan Politik

Anne Philips dalam The Politics of Presence mengintrodusir dua model keterwakilan politik, yaitu politics of idea(politik gagasan) dan politics of presence (politik representasi). Teori Anne phillips mengatakan bahwa umunya keterwakilan politik saat ini wujud dari konsep politik gagasan, dimana wakil politik membawa berbagai gagasan atau pemikiran dari orang-orang yang diwakilinya. Namun, dengan diterapkannya sistem pemilihan melalui partai politik, sering kali para pemilih hanya memilih berdasarkan pada partai tanpa lebih dekat mengenal dan mengetahui latar belakang calon wakilnya tersebut. Hal ini menjadikan anggota parlemen bukan wakil dari rakyat melainkan wakil dari partai. Selain itu anggota parlemen sering juga tidak menyampaikan kembali seluruh pemikiran dan aspirasi yang diperoleh dari para pemilihnya. Mereka lebih sering mengutamakan gagasan komunitas tertentu yang lebih lekat dengan idenstitas dirinya, termasuk jenis kelamin. Hal ini menurut Phllipis berdampak dengan dirugikannya kelompok-kelompok minoritas seperti perempuan yang memiliki angka 
keterwakilan yang rendah di lembaga parlemen.

Demi melihat bentuk tersebut Phillips memuncul bentuk politik kehadiran sebagai bentuk ideal keterwakilan politik. Politik kehadiran menempatkan keterwakilan politik secara acak sesuai komposisi yang pada akhirnya mampu menyalurkan kepentingan kelompok dengan baik. Menurut Phillips tidak mungkin kepentingan kelompok marjinal dapat tersalurkan jika tidak ada anggota yang terlibat dalam parlemen.

Phillips membagi kehadiran menjadi beberapa sifat yaitu deskriptif, substantif, dan transformatif personal. Kehadiran deskripstif mengacu pada kehadiran fisik perempuan di lembaga politik, ekonomi dan sosial. Dimana kehasidaran mereka menjadi simbol perempuan ada dilembaga tersebut sesuai ketentuan kuota. Kehadiran substantif adalah kehadiran wakil perempuan berusaha sebaik mungkin atas keinginan dan kehendak orangorang yang diwakilinya. Terakhir kehadiran transformatif secara personal berarti dampak kehadiran itu pada diri identitas. Dengan kata lain kehadiran transformatif ini memiliki pengaruh untuk mengubah diri mereka, mengubah peran mereka dan mengembangkan kapasitas mereka dalam menjalankan fungsinga sebagai anggota legislatif.

\section{Konsep Fungsi Legislatif}

Badan Legislatif yang berkedudukan sebagai lembaga negaraterdiri atas anggota partai politik peserta pemilihan umum yang dipilih berdasarkan hasil pemilihan umum. Dimana fungsi badan legislatif meliputi fungsi legislasi, fungsi anggaran, dan fungsi pengawasan.

Terkait dengan fungsi legislasi, badan legislatif memiliki tugas dan wewenang: Menyusun Program Legislasi Nasional (Prolegnas), Menyusun dan membahas Rancangan Undang-Undang (RUU), Menerima RUU yang diajukan oleh DPD (terkait otonomi daerah; hubungan pusat dan daerah; pembentukan, pemekaran dan penggabungan daerah; pengelolaan SDA dan SDE lainnya; serta perimbangan keuangan pusat dan daerah), Membahas RUU yang diusulkan oleh Presiden ataupun DPD, Menetapkan UU bersama dengan Presiden, Menyetujui atau tidak menyetujui peraturan pemerintah pengganti UU (yang diajukan Presiden) untuk ditetapkan menjadi UU

Terkait dengan fungsi anggaran, badan legislatif memiliki tugas dan wewenang: Memberikan persetujuan 
atas RUU tentang APBN (yang diajukan Presiden), Memperhatikan pertimbangan DPD atas RUU tentang APBN dan RUU terkait pajak, pendidikan dan agama, Menindaklanjuti hasil pemeriksaan atas pengelolaan dan tanggung jawab keuangan negara yang disampaikan oleh BPK, Memberikan persetujuan terhadap pemindah tanganan aset negara maupun terhadap perjanjian yang berdampak luas bagi kehidupan rakyat yang terkait dengan beban keuangan negara.

Terkait dengan fungsi pengawasan, badan legislatif memiliki tugas dan wewenang:Melakukan pengawasan terhadap pelaksanaan UU, APBN dan kebijakan pemerintah, Membahas dan menindaklanjuti hasil pengawasan yang disampaikan oleh DPD (terkait pelaksanaan UU mengenai otonomi daerah, pembentukan, pemekaran dan penggabungan daerah, pengelolaan SDA dan SDE lainnya, pelaksanaan APBN, pajak, pendidikan dan agama)

Keputusan berdasarkan suara terbanyak diambil apabila keputusan berdasarkan mufakat sudah tidak terpenuhi karena adanya pendirian sebagian anggota rapat yang tidak dapat dipertemukan lagi dengan pendirian anggota rapat yang lain. Pengambilan keputusan secara terbuka dilakukan apabila menyangkut kebijakan dan dilakukan secara tertutup apabila menyangkut orang atau masalah lain yang dianggap perlu. Pemberian suara secara tertutup dilakukan dengan cara tertulis, tanpa mencantumkan nama, tanda tangan, fraksi pemberi suara atau tanda lain yang dapat menghilangkan sifat kerahasiaan, atau dapat juga dilakukan dengan cara lain yang tetap menjamin sifat kerahasiaan.Keputusan berdasarkan suara terbanyak adalah sah apabila diambil dalam rapat yang telah mencapai kuorum dan disetujui oleh lebih separuh jumlah anggota yang hadir.

\section{Konsep Perilaku Memilih}

Untuk menjelaskan perilaku memilih dikenal dua macam pendekatan yaitu Mazhab Columbia yang menggunakan pendekatan Sosiologi dan Mazhab Michigan yang dikenal dengan pendekatan Psikologis. Selain itu juga terdapat pendekatan pilihan rasional yang melihat perilaku seseorang melalui kalkulasi untung rugi yang didapat oleh individu tersebut.

Pendekatan sosiologi ini pada dasarnya menjelaskan bahwa karakteristik sosial dan pengelompokan-pengelompokan sosial 
mempunyai pengaruh yang cukup signifikan dalam menentukan perilaku pemilih. Peranan masyarakat dilihat sebagai sistem yang mempunai stratifikasi, dan kajian terhadap pekerjaan serta kedudukan seeorang di tengah masyarakat sengat penting dalam memahami perilaku pemilih. Pendekatan sosiologi mengasumsikan bahwa prefensi partai politik sebagaimana juga prefensi voting adalah produk karateristik sosioekonomi seperti pekerjaan, agama dan ideologi. Pengelompokan sosial seperti umur (tua-muda). jenis kelamin (laki-laki dan perempuan), agama dan semacamnya dianggap mempunyai peranan yang cukup menentukan dalam membentuk perilaku memilih.

Pendekatan psikologis muncul merupakan reaksi atas ketidakpuasan mereka terhadap pendekatan sosiologis. Secara metodelogis, pendekatan sosiologis diaangap sulit diukur, seperti bagaimana mengukur secara tepat sejumlah indikator kelas sosial, tingkat pendidikan, agama dan sabagainya. Dalam konteks pilihan rasional ada analogi antara pasar (ekonomi) dan perilaku memilih (politik). ketika pemilih merasa tidak mendapatkan keuntungan dengan memilih partai atau calon yang sedang berkompetisi, maka ia tidak akan memilih ketika pemilu dilaksanakan. Hal itu dilandasi pada kalkulasi ekonomi, apabila perhitungan biayai yang dikeluarkan lebih besar dengan apa yang akan didapatnya kelak maka jalan terbaik bagi pemilih tersebut adalah melakukan aktivits sehariharinya.

Pendekatan rasional mengantarkan kita pada kesimpulan bahwa pemilih benar-benar rasional. Pemilih rasional memiliki motivasi, prinsip, pengetahuan dan informasi yang cukup, tindakan mereka bukanlah karena kebetulan.

\section{METODE PENELITIAN}

Dalam penelitian ini, peneliti menggunakan metode pendekatan kualitatif dengan jenis pendekatan Studi Kasus. Studi kasus digunakan untuk memenuhi keinginantahuan peneliti karena ketertarikan pada persoalan kontribusi anggota legislatif perempuan di DPRD Kabupaten Bungo. Alasannya, peneliti ingin menggali informasi secara mendalam alasan mengapa para anggota legislatif perempuan di DPRD Kabupaten Bungo tidak bisa memberikan kontribusi terhadap kepentingan perempuan di Kabupaten Bungo. Dengan penggunaan metode ini diharapkan dapat menjelaskan dan menggambarkan alasan-alasan dan 
penyebab sebenarnya anggota legislatif perempuan tersebut tidak bisa berkontribusi. Bukan untuk membangun teori tertentu.

Penggunaan metode studi kasus pada kasus tidak adanya kontribusi anggota legislatif perempuan terhadap kepentingan perempuan di Kabupaten Bungo merupakan sebuah metode yang dianggap peneliti tepat untuk mendapatkan jawaban terhadap fenomena yang peneliti angkat. Teori tentang keterwakilan perempuan di badan legislatif yang dikemukakan oleh Anne Phillip seharusnya mampu menjelasakan fenomena yang ada terkait hal itu. Tetapi penggunaan metode studi kasus dalam pengumpulan data penelitian ini, teori tersebut belum lengkap dalam menjelaskan fenomena. Sehingga peneliti berasumsi bawa teori tersebut perlu dimodifikasi atau diprakarya. Disinilah keunikannya sehingga alasan memilih metode studi kasus ini bisa terjawab

\section{HASIL DAN PEMBAHASAN}

Hasil dan analisa data ini membahas fakta dan temuan-temuan yang didapatkan oleh peneliti dilapangan selama proses penelitian. Hasil data tersebut berupa informasi yang diperoleh melalui wawancara mendalam dengan berbagai informan baik itu informan kunci maupun informan dari triangulasi kemudian diinterpresentasikan dengan teori dan data informan. Serta beberapa dokumen atau artikel yang menyangkut mengenai anggota legislatif perepuan di DPRD Kabupaten Bungo. Penelitian ini mengambil beberapa informan dari masing-masing karakter objek yang diteliti. Hasil yang diperoleh dalam penelitian ini dijabarkan dalam bentuk dan konsep keterwakilan perempuan dalam lembaga legislatif, terutama dalam menjawab permasalahan kontribusi anggota legislatif perempuan DPRD Kabupaten Bungo Periode 20142019 ditinjau melalui keterwakilan politik perempuan.

Penelitian tentang keterwakilan politik perempuan di lembaga legislatif, khususnya dalam lembagwa perwakilan seperti DPRD adalah upaya untuk menjelaskan fenomena keterwakilan perempuan tersebut dalam lembaga perwakilan rakyat. Dalam penelitian ini peneliti menemukan beberapa temuan awal terkait keterwakilan perempuan tersebut di lembaga legislatif, tepatnya di DPRD Kabupaten Bungo. 
Ada berbagai alasan yang dikemukakan untuk menjelaskan mengapa perempuan terjun ke dunia politik, salah satunya bergabung dengan partai politik. Keiikutsertaan itu biasanya diawali dari ajakan anggota partai yang bersangkutan untuk bergabung. Berdasarkan pada wawancara mendalam yang dilakukan peniliti terhadap anggota legislatif perempuan terungkap bahwa syarat utama untuk menjadi anggota legislatif itu adalah uang. Kepintaran dan pengetahuan mengenai politik tidak menjadi persoalan asal calon anggota legislatif tersebut memiliki uang. Politik dan uang merupakan dua hal yang memang tidak dapat dipisahkan dalam kontestasi politik di Indonesia. Politik uang memang menjadi suatu hal yang menarik untuk dibahas baik dalam pemilu baik pileg maupun pemilihan kepada daerah, praktek politik uang sering terjadi. Seperti penelitian yang telah dilakukan oleh Edward Aspinal dan Mada Sukmajati di Bangka Belitung Tahun 2014. Dalam penelitian ini peneliti mengutip konsep dari Mada Sukmajati bahwa dalam politik uang (votes buying) ada hubungan korelasi antara Patronase dan Klientalisme. Dalam temuan peneliti terungkap bahwa tawaran memberikan uang bukan datang dari caleg saja, tetapi masyarakat juga lebih berani meminta kompensasi atas suara mereka. Setiap datang sosialisasi yang dilakukan baik oleh caleg sandiri maupun tim kampanye, yang ditanyakan masyarakat adalah seberapa banyak yang bisa diberikan oleh caleg. Dengan kondisi seperti ini, jelas caleg yang bermodal besar lebih berpeluang jadi dibandingkan mereka yang memiliki kapasitas intelektual maupun sosial.

Dari wawancara di atas dengan sejumlah informan, menurut peneliti motivasi mereka untuk berperan aktif dalam kegiatan politik seperti menjadi anggota legislatif DPRD Kabupaten Bungo belum disadari atas mewakili kepentingan perempuan. Melainkan hanya memanfaatkan peluang untuk tujuan pribadi. Sehingga setelah menjadi anggota legislatif mereka tidak bisa menyuarakan apa yang menjadi kepentingan perempuan di Kabupaten Bungo.

Masalah itu merupakan masalahmasalah yang dihadapi perempuan di Kabupaten Bungo terkait dengan kepentingan perempuan sama sekali tidak pernah menjadi perhatian para anggota legislatif perempuan di DPRD Bungo. Hal ini terbukti dengan jumlah 
Peraturan Daerah yang dihasilkan pada periode 2014-2019 tidak ada yang terkait dengan kepentingaN perempuan. Walaupun kasus kekerasan pada perempuan tahun 2018 jumlah kasusnya mengalami penurunan dibandingkan tahun sebelumnya tetap harus ada perlindungan terhadap perempuan yang dilakukan oleh anggota legislatif perempuan di DPRD.

Anggota legislatif perempuan DPRD Kabupaten Bungo periode 2014-2019 selama menjalankan tugas sebagai anggota dewan belum menjalankan fungsi yang dimiliki sebagai anggota dewan menyangkut kepentingan perempuan yang diwakilinya. Kesadaran anggota legislatif perempuan sebagai wakil perempuan belum terbangun, tingkat pendidikan juga menjadi persoalan anggota legislatif perempuan belum bisa berkontribusi terhadap kepentingan perempuan. Sehingga dapat disimpulkan bahwa anggota legislatif perempuan DPRD Kabupaten Bungo periode 2014-2019 masih tergolong ke dalam politik kehadiran deskriptif.

\section{KESIMPULAN}

Peningkatan jumlah keterwakilan perempuan di DPRD Kabupaten Bungo ternyata tidak sejalan dengan kepentingan perempuan. Hal ini terbukti dengan enam anggota legislatif perempuan yang ada tidak bisa memberikan kontribusi terhadap kepentingan perempuan. Kehadiran mereka di DPRD hanya sebatas kehadiran deskriptif, tidak termasuk kepada kehadiran subtantif apalgi kehadiran transformatif (Politics of Presence). Sehingga mereka tidak bisa memberikan gagasan dan ide-ide (Politics of Idea) yang terkait dengan masalah serta isu-isu perempuan di Kabupaten Bungo. Tidak ada pertarungan ide-ide yang terjadi didalam rapat-rapat yang dilaksanakan di DPRD Kabupaten Bungo yang menyuarakan kepentingan perempuan.

Hasil dari penelitian menunjukkan bahwa penyebab anggota legislatif perempuan itu tidak bisa berkontribusi adalah pertama, aleg perempuan tidak memahami keterwakilan perempuan sehingga tidak bisa mengeluarkan pendapat dan memberikan usulan di dewan mengenai isu-isu yang berkaitan dengan kepentingan perempuan untuk dituangkan dalam sebuah kebijakan yang produktif. Kedua, motivasi awal aleg perempuan ikut pemilihan legislatif karena uang dan peluang. Politik uang sangat menentukan keberhasilan calon perempuan dalam memperoleh 
dukungan konstituen melalui jejaring yang mereka bentuk. Tidak ada kesadaran bahwa keberadaan aleg di DPRD merupakan perpanjangan tangan dari kaum perempuan yang ada. Hal ini karena tujuan awal terjun ke politik dan mengikuti pileg adalah uang. Ketika terpilih membuat aleg tidak harus memberikan kontribusi terhadap yang memilih, hubungan patronase dan klientalisme telah berakhir sejalan dengan berakhir pemilu.

Jaminan perlindungan terhadap hak keterwakilan perempuan di parlemensebagaimana telah dijamin oleh konstitusi, ditindaklanjuti pada tingkat peraturan perundang-undangan di bawahnya. Meskipun UU Nomor 8 Tahun 2012 tentang pemilu legislatif sebagai pengganti UU Nomor 10 Tahun 2008 telah mengakomodir sistem suara terbanyak, namun upaya untuk

\section{Daftar Pustaka}

A Afrizal, 2014, Metode Penelitian Kualitatif. Jakarta : Raja Grafindo Persada.

Anugrah, Astrid, 2009. Keterwakilan Perempuan Dalam Politik, Jakarta:

Dwipayana, Ari 2010. Globalism: pergulatan Politik Represntasi Atas Bali. Denpasar: Uluangkep Press

Hanim, Razya, 2010, Perempuan dan Politik:Studi Kepolitikan Perempuan di DKI Jakarta, Jakarta: Madani Institute meningkatkan jumlah keterwakilan kaum perempuan di parlemen belum begitu nampak terlihat dalam UU ini. Untuk itu, tindak lanjut yang dapat dilakukan untuk mengupayakan peningkatan jumlah keterwakilan kaum perempuan di parlemen adalah melakukan perubahan UU Pemilu Legislatif dengan mewajibkan partai politik untuk memuat satu calon perempuan dari tiga calon anggota legislatif yang diusulkan dari setiap dapil, dengan diiringi sanksi jika hal tersebut tidak dipenuhi oleh partai politik pengusung maka parpol yang tidak memenuhi syarat tersebut, tidak diperkenankanmengikuti pemilu pada dapil yang bersangkutan.

Isbodroini, Suyanto. Peranan Sosialisasi Politik terhadap Partisipasi Politik Perempuan, dalam Kajian Pembangunan Wanita. Jakarta: Yayasan Obor Indonesia

Indar Parawansa, Khofifah, 2002, Hambatan Terhadap Patisipasi Perempuan di Indonesia, dalam Perempuan di Parlemen: Bukan Sekedar Jumlah, Internasional IDEA , JakartaMoh. Nazir, 2003, Metode Penelitian, Jakarta: Penerbit Ghalia Indonesia.

Komarudin, 1991. Uang Di Negara Sedang Berkembang, Jakarta: Bumi Aksara 
Mars, David (dkk), 2000. Teori dan Metode dalam Ilmu Politik, Bandung: Nusa Media,

Megawangi, Ratna, 1999. Membiarkan berbeda? Sudut Pandang Baru Tentang RelasiGender, Bandung, Mizam Pustaka.

Sugiyono, 2013. MetodoPenelitian Kuantitatif, Kualitatif dan $R \& D$, Bandung: ALFABETA

Surbakri, Ramlan, Memahami Ilmu Politik, Jakarta: Gramedia Widya Sarana

Phillips, Anne, 1998. The Politics Of Presence, Newyork: Oxford University Press Inc $e$-book

Widjaja, H.A. 2002, Otonomi Daerah dan Daerah Otonomi, Raja Grafindo Persada, Jakarta,

Yin, Robert K. 2003. Penelitian Studi Kasus: Desain dan Metode. Edisi ketiga. Sage Publications, London

Yusi, Syahirman, dan Idris, Umiyati, 2009. Metodologi Penelitian IImu Sosial: Pendekatan Kuantitatif, Citra Book Indonesia.

\section{Jurnal dan Artikel}

Adelina, Novi Yanthy, Jurnal Hukum Vol 7. No 2, Keterwakilan Perempuan di DPRD Provinsi Sumatera Utara Periode 2009-2014, Fakultas Hukum Universitas Andalas.

Asep Ridwan, Memahami Perilaku Pemilih pada Pemilu 2004 di Indonesia, Jurnal Demokrasi dan HAM

Budiarti, Aisah Putri, 2011. Jurnal Studi Politik vol. 1,No 2,Bayang-Bayang Afirmasi Keterwakilan Perempuan di Parlemen, Depok: Departemen Ilmu Politik FISIPUI
Dessi Artina, 2016, Jurnal Hukum Vol 23 No 1, Keterwakilan Politik Perempuan dalam Pemilu Legislatif

Provinsi Riau Periode 2014-2019, Fakultas Hukum Universitas Riau, Pekan Baru

Dirga Ardiansa, Menghadirkan Kepentingan Perempuan dalam Representasi Politik di Indonesia, 2015 diakses pada https://www.puskapol.ui.ac.id pada tanggal $11 \quad$ Juli 2019

Elfi Mu'awannah, 2015, Jurnal Perempuan Vol 11 No 2, Keterwakilan Perempuan dalam Ranah Politik dan Urgensi Keterwakilannya, STIAIN, Tulungagung

Haryani, Dewi Susilastuti, 2013, Kepempimpinan Perempuan: Perubahan Paradigma dari Politik Gagasan ke Politik Kehadira, Jurnal Perempuan ,Pusat Studi Kependudukan dan Kebijakan, Universitas Gajah Mada

Idris, N,2010, Jurnal Sosial Politik, ,No. 02,. Minat Perempuan Minangkabau

Adi Prayitno, Politik Berparas Perempuan, 2014 https://nasional.sindonews.com/read /845514/114/politik-berparasperempua- $\quad 194 \quad 3777$

Diakses pada tanggal 25 Maret 2019

Dirga Ardiansa, Menghadirkan Kepentingan Perempuan dalam Representasi Politik di Indonesia, 2015 Diakses pada https://www.puskapol.ui.ac.id pada tanggal 11 Juli 2019 